\title{
The Other('s) Toronto Public Art: The Challenge of Displaying Canadians' Narratives in a Multicultural/Diasporic City
}

\section{Analays Alvarez Hernandez}

Volume 44, numéro 1, 2019

URI : https://id.erudit.org/iderudit/1062151ar

DOI : https://doi.org/10.7202/1062151ar

Aller au sommaire du numéro

\section{Éditeur(s)}

UAAC-AAUC (University Art Association of Canada | Association d'art des universités du Canada)

\section{ISSN}

0315-9906 (imprimé)

1918-4778 (numérique)

Découvrir la revue

\section{Citer cet article}

Hernandez, A. A. (2019). The Other('s) Toronto Public Art: The Challenge of Displaying Canadians' Narratives in a Multicultural/Diasporic City. RACAR : Revue d'art canadienne / Canadian Art Review, 44(1), 42-53.

https://doi.org/10.7202/1062151ar
Résumé de l'article

Cet article explore les controverses sévissant autour de quelques oeuvres permanentes d'art public commémoratif, commandées ou financées par le public ou le privé, qui ont été érigées à Toronto afin de représenter des récits nationaux et extranationaux associés à des communautés ethnoculturelles. À travers l'analyse de plusieurs études de cas, nous démontrons comment et pourquoi la population immigrante au Canada, en pleine augmentation et diversification, a une incidence sur la gestion de l'art public commémoratif dans ce pays. En conclusion, nous recommandons l'adoption de pratiques contemporaines en art public comme un moyen de commémorer autrement et de maintenir la cohésion sociale dans une ville multiculturelle et diasporique comme Toronto.
Tous droits réservés (C) UAAC-AAUC (University Art Association of Canada | Association d'art des universités du Canada), 2019
Ce document est protégé par la loi sur le droit d'auteur. L'utilisation des services d'Érudit (y compris la reproduction) est assujettie à sa politique d'utilisation que vous pouvez consulter en ligne.

https://apropos.erudit.org/fr/usagers/politique-dutilisation/ 


\title{
The Other('s) Toronto Public Art: The Challenge of Displaying Canadians' Narratives in a Multicultural/Diasporic City ${ }^{1}$
}

\author{
Analays Alvarez Hernandez
}

\begin{abstract}
Cet article explore les controverses sévissant autour de quelques œuvres permanentes d'art public commémoratif, commandées ou financées par le public ou le privé, qui ont été érigées à Toronto afin de représenter des récits nationaux et extranationaux associés à des communautés ethnoculturelles. À travers l'analyse de plusieurs études de cas, nous démontrons comment et pourquoi la population immigrante au Canada, en pleine augmentation et diversification, a une incidence sur la gestion de l'art public commémoratif dans ce pays. En conclusion, nous recommandons l'adoption de pratiques contemporaines en art public comme un moyen de commémorer autrement et de maintenir la cohésion sociale dans une ville multiculturelle et diasporique comme Toronto.
\end{abstract}

Analays Alvarez Hernandez is an independent curator and parttime professor in the Department of Visual Arts at the University of Ottawa.

-aalvare3@uottawa.ca

1. This paper discusses some findings of a postdoctoral research project sponsored between 2016 and 2018 by the Fonds de recherche du Québec-Societé et Culture, University College (University of Toronto), and the Canadian Art Commons for History of Art Education and Training (CACHET). The project included the creation of an online registry and exhibition featuring over 80 ethno-cultural monuments erected in Toronto, Vancouver, and Montreal. See www.ethnoculturalmonuments.ca.

2. Quentin Stevens, "Masterplanning public memorials: an historical comparison of Washington,

\section{$\underline{\text { Introduction }}$}

Urban design scholar Quentin Stevens has pointed out that, in today's democratic cities, "public memorials are rarely initiated or designed by the executive branch of the national government, but rather by diverse groups with differing interests." 2 This is particularly true in multicultural and diasporic nations such as Canada, where new elites that want and fund public art have emerged, ranging from European settler groups to transnational and ethno-cultural communities who, over time, have achieved political and economic recognition in their host society.

The aim of this article is to suggest the adoption of alternative forms of remembrance, as opposed to more traditional and permanently installed ones such as busts or figurative sculptures, given the complexity of commissioning commemorative public art in Toronto, especially when ethno-cultural minorities are involved in the process. After explaining the concept of the "ethno-cultural monument" and outlining my research approach and methods, I discuss the striking contrast between Toronto's former public art donation policy, in effect since 2001, and the current one, introduced in 2017. For commemorative artworks, the new policy grants a great deal of importance to the "Canadianness" of topics and subjects represented. This (nationalistic) emphasis seems to reflect the municipal administration's concern to achieve social cohesion in a city that embraces more than two hundred nationalities.

Achieving social cohesion, that is, reaching levels of trust and civic engagement that allow attainment of common goals, ${ }^{3}$ remains one of the major challenges for nations receiving ever-greater numbers of immigrants. The relationship between social cohesion and ethno-cultural diversity has been explored by scholars, including in Canada, ${ }^{4}$ but though this topic has been intensely debated on in the fields of political sciences and economics, little work has been done to situate it in terms of public art. I explore why and how existing ethno-cultural monuments and demands for new memorials from ethno-cultural minorities are perceived to challenge or threaten the cohesion of Canadian society.

The second part of this article presents a series of case studies that exemplify issues and controversies that might have led to the rescinding of the 2001 Toronto public art donation policy. I demonstrate how ethno-cultural minorities, through the erection of commemorative public art, oscillate between practices of place-making and legitimation. My case studies 
Ottawa and Canberra," Planning Perspectives 30, no. 1 (2015): 39.

3. Merlin Schaeffer, Ethnic Diversity and Social Cohesion: Immigration Ethnic Fractionalization and Potentials for Civic Action (Burlington, vT: Ashgate, 2014).

4. See, for instance, Ibid.; Stuart N. Soroka, Richard Johnston, and Keith Banting, "Ties that Bind? Social Cohesion and Diversity in Canada," in Belonging? Diversity, Recognition and Shared Citizenship in Canada, ed. Keith Banting, Thomas Courchene, and F. Leslie Seidle (Montreal: Institute for Research on Public Policy, 2006), 561-600; Jeffrey G. Reitz et al., Multiculturalism and Social Cohesion: Potentials and Challenges of Diversity (New York: Springer Science \& Business Media, 2009).

5. This definition was formulated in 1903 by the Austrian art historian Alois Riegl in his seminal essay "The Modern Cult of Monuments: Its Character and Its Origin," trans. Kurt W. Forster and Diane Ghirardo, Oppositions 25 (Fall 1982): 21-51.

6 . This paper is not the place to rehearse the extensive debate on the difference between a monument and a memorial; however, it is important to note that the term ethno-cultural monument comprises both.

7. John Warkentin, Creating Memory: A Guide to Outdoor Public Sculpture (Toronto: Becker Associates, 2010), 3 .

8. "Sibelius Bust Given Toronto," The Globe and Mail, Monday, Sept. 21, 1959: 4.

9. Although it falls outside the scope of this article, one could not ignore the reality that a great number of ethno-cultural monuments, especially those which stand on public land and have received governmental sanction, are created by Caucasian males who, in some cases, have no historical connection to the communities that initiated and financed the works.

10. See, Charles Taylor, "The Politics of Recognition," in Multiculturalism: Examining the Politics of Recognition, ed. Amy Gutmann (Princeton University Press, 1994), 25-73; Will Kymlicka, Multicultural Citizenship: A Liberal Theory of Minority Rights (Oxford: Oxford University Press, 1995), Finding Our Way: Rethinking Ethnocultural Relations in Canada (Oxford: Oxford University Press, 1998); Augie Fleras and Jean Leonard Elliott, Engaging Diversity: Multiculturalism in Canada (Scarborough, ON: Nelson Thomson Learning, 2002); Janice Stein et al., eds., Uneasy Partners: Multiculturalism and Rights in Canada (Waterloo, on: Wilfrid Laurier University Press, do not include all ethno-cultural monuments in Toronto, but only those that-before, during, and after their construction-have generated public debates and confrontations. Although my point of departure is visual culture, I do not explore here the symbolic, aesthetic, or design relevance of the monuments in question: I am rather concerned with the socio-political tensions surrounding their conception and materialization, and their reception and perception over time. Finally, I point out the urgency of finding public art-related alternative solutions in order to reconcile social cohesion and ethno-cultural minorities' place-making and historical legitimation processes in plural societies.

\section{Defining the Ethno-Cultural Monument}

"Ethno-cultural monuments" correspond to the longstanding definition of a monument: a publicly placed work of art with a deliberate commemorative value. ${ }^{5}$ That said, they are also a unique and socially important form of public art. I have coined the term to describe monuments and memorials, ${ }^{6}$ often aesthetically conservative, that are generally the fruit of communal efforts led by diasporic groups and occasionally supported by distinct levels of government. Ethno-cultural monuments are typically located at sites that can physically accommodate commemorative activity and they generally bear an inscription or plaque encapsulating the commemorated subject, which is essential to the fixing of their meaning.

The first ethno-cultural monument in Toronto was erected in 1902, when the Toronto Burns Monument Committee, led by local individuals of Scottish descent, commissioned a statue to honor Robert Burns in Allan Gardens. | fig. 1 | For more than a century, the life-size effigy of the Scottish poet has dwelled in this public park. This monument, exceptional at the time because it represents an ethnic community, was "a harbinger of what was to come in the last half of the twentieth century when other immigrants also wanted to honor their forebears," according to historical geographer John Warkentin. ${ }^{7}$ The next monument commissioned by an ethno-cultural community found its way into Toronto's public realm when a bust of Finland's national composer Jean Sibelius | fig. 2 | was presented on September 20, 1959 , to the City of Toronto on behalf of Finnish Canadians. ${ }^{8}$ The bust honouring Sibelius began a new chapter for monuments and memorials that convey immigrant narratives. Since the 1960 s, ethno-cultural communities in Toronto have frequently initiated and funded works that publicly commemorate or celebrate heroes, victims, and events in relation either to their homeland or to their history in Canada. Today, Toronto's open spaces accommodate approximately 40 ethno-cultural monuments; these are generally placed in parks or on the grounds of universities, places of worship, or community centers. For the most part, these memorial artifacts are entirely community-funded through associations, foundations, committees, and other types of charity organization. ${ }^{9}$

\section{Approaching Ethno-Cultural Monuments: Methods and Research Strategies}

Since the 1990s, a significant amount of scholarly research has focused on multicultural policy in Canada. ${ }^{10}$ Issues pertaining to cultural diversity and 


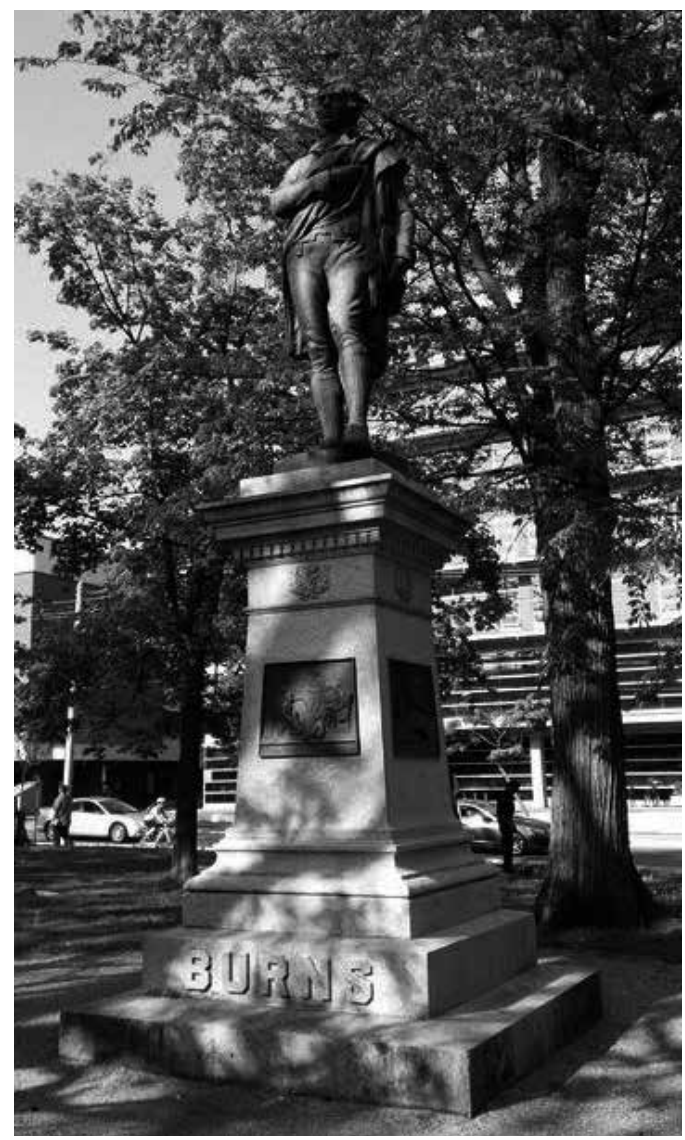

Figure 1. David Watson

Stevenson. Statue of Robert

Burns. Allan Gardens, Toronto.

1902. Bronze. Photo by the author.

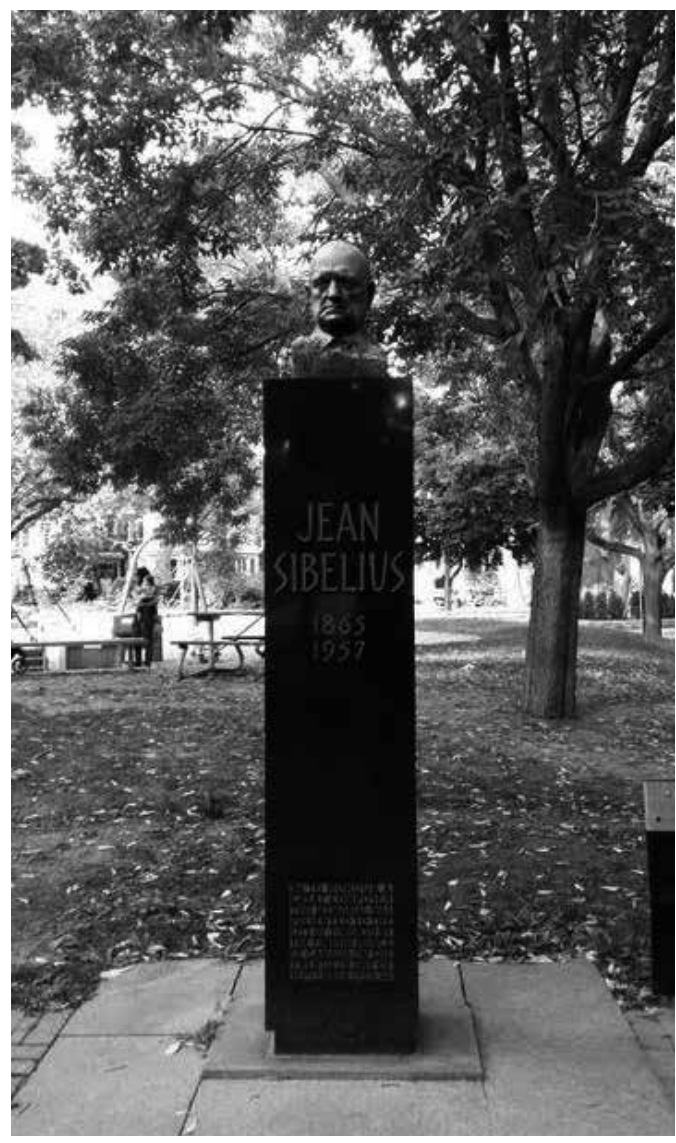

Figure 2. Wäinö Aaltonen.

Bust of Jean Sibelius. Jean

Sibelius Park, Toronto. 1959.

Bronze. Photo by the author. 
2007); May Chazan et al., eds., Home and Native Land: Unsettling Multiculturalism in Canada (Toronto: Between the Lines, 2011); and Shibao Guo and Lloyd Wong, eds., Revisiting Multiculturalism in Canada: Theories, Policies and Debates (Rotterdam: Sense Publishers, 2015).

11. See, for instance: Susan Ashley, “Museum-making: 'New' Canadians reimagine heritage and citizenship," Representation and Citizenship, ed. Richard Marback (Detroit: Wayne State University Press, 2016), 156-70; Caitlin Gordon-Walker, Exhibiting Nation:Multicultural Nationalism (and Its Limits) in Canada's Museums (Toronto and Vancouver: UBC Press, 2016).

12. Paul Ashton and Paula Hamilton conducted a national study on non-war memorials constructed in Australia since the 1960 s. Their study revealed, among other findings, an increase of memorials related to migrants' communities. See Paul Ashton, Paula Hamilton and Rose Searby, Places of the Heart: Memorials in Australia (Melbourne: Australian Scholarly Publishing, 2012).

13. Michele H. Bogart, The Politics of Urban Beauty: New York and Its Art Commission (Chicago: University of Chicago Press, 2006), 101.

14. Ibid.

15. Caitlin Gordon-Walk-

er, "Mapping National Identity," in Cultural Challenges of Migration in Canada, ed. Klaus-Dieter Ertler and Patrick Imbert (Frankfurt: Peter Lang, 2014), 209-222.

16. Jenny Burman, "Divergent Diversities: Pluralising Toronto and Montreal," in Urban Enigmas, Montreal, Toronto, and the Problem of Comparing Cities, ed. Johanne Sloan (Montreal and Kingston: McGill-Queen's University Press, 2007), 255-73. inclusiveness in museums have been thoroughly explored in recent scholarship. ${ }^{11}$ Yet the relation between public art and immigrant populations in Canada is a field critically unexplored. One barrier to scholarly work on this topic is that, for commemoration practices led by communities, little documentation may be available. In undertaking research on this subject, I have adopted a qualitative and ethnographic approach, relying on field research and on the analysis of newspaper articles (especially from community and regional papers), online resources, and such primary sources as reports of municipal councils and meeting minutes, public art guidelines and policies, and municipal and provincial archival documents.

In order to better understand Canadian ethno-cultural monuments as part of a globalized phenomenon, we can turn to similar settler contexts such as Australia ${ }^{12}$ and the United States, where there is also debate on ethno-cultural diversity, commemorative public art, and social cohesion. Michele $\mathrm{H}$. Bogart's book The Politics of Urban Beauty: New York and Its Art Commission provides an in-depth-though more empirical than theoretical-analysis of the Art Commission of New York (ACNY) through an account of disputes, compromises, and negotiations over the insertion of elements of urban design into the city's landscape. ${ }^{13}$ Although Bogart, an art historian and former vice-president of the ACNY, grants the highest significance (maybe too much) to aesthetic considerations, visual coherence, and artistic trends in the process of shaping cities' landscapes, I share her understanding of the role and functions of the ethno-cultural monument. Bogart notably argues that memorials and monuments initiated by organizations and individuals representing immigrants in New York in the first decades of the twentieth century, when the city was growing in importance, were (and still are) "deliberate assertions of ethnic presence, pride, and political power." ${ }^{14}$

\section{Immigrant Populations and Commemorative Public Art}

There has been a growing demand from immigrant groups for commemorative works of public art in Canada over the past three or four decades. This can be explained by the conjunction of four main factors. First, to promote equality, the Canadian federal government adopted in 1971 a multiculturalism policy that grants non-dominant ethno-cultural groups public recognition and accommodation of cultural and religious differences.

Second, the growth in demand for ethno-cultural public art is closely related to changes in migration patterns, which are no longer single and unidirectional movements from one place to another. Migrants travel back and forth between places, and this keeps alive connections to their places of origin. ${ }^{15}$ When discussing the status of Toronto as a "diasporic city," McGill University communication studies professor Jenny Burman argues that such living connections, whether emotional, financial, or historical, to places of origin (or to multiple places), as well as the circulation of people, cultural influences, and objects, charge such cities as Toronto with extra-national narratives. ${ }^{16}$

Third, after the Second World War, immigrants and refugees started coming to Canada in increasingly large numbers (many to Toronto), not only from Europe, but also from other parts of the world. This trend has gained momentum since the early $1980 \mathrm{os}$. The number of immigrants from Asia, Africa, and 
17. Guo and Wong, Revisiting Multiculturalism in Canada.

18. On memory culture, see Andreas Huyssen, Twilight Memories: Marking Time in a Culture of Amnesia (New York: Routledge, 1995); Present Pasts: Urban Palimpsests and the Politics of Memory (Stanford, CA: Stanford University Press, 2003); David Simpson, 9/11: The Culture of Commemoration (Chicago and London: The University of Chicago Press, 2006); Erika Doss, Memorial Mania: Public Feeling in America (Chicago and London: The University of Chicago Press, 2010); Andrew Hoskins, "Media and the closure of the memory boom," in Media and Nostalgia: Yearning for the Past, Present and Future, ed. Katherina Niemeyer (Houndmills: Palgrave Macmillan, 2014)

19. Bogart, The Politics of Urban Beauty, 95.

20. Sally Han [Manager, Cultural Partnerships, City of Toronto], phone interview by the author, Toronto, Dec. 8, 2016.

21. In recent years, many groups of citizens, not only ethno-cultural groups, have approached the municipal government regarding matters of commemoration. Indeed, since 2014, fifteen public art proposals have been submitted to the City. Two of those proposals have resulted in the installation in 2016 of a permanent work of public art or memorial: the Italian Canadian War Veterans Monument and the statue of Jeffrey Baldwin, a Toronto infant who met a tragic death in 2002. One proposal for a monument to the Holodomor has been approved by City Council. The work was recently unveiled, on October 21, 2018. See: City of Toronto, "Report for Action: Public Art and Monuments Donation Policy." Dec. 21, 2016. http://www.toronto.ca/legdocs/ mmis/2017/ex/bgrd/backgroundfile-99599.pdf (accessed Feb 10, 2017)

22. City of Toronto, Strategic Protocol and External Relations, "Official Gift Donations," https:// www1.toronto.ca/wps/portal/contentonly?vgnextoid=43e87aac783a1410 VgnVCM10000071d6of8gRCRD\&vgnextchannel=62264a1646891410VgnVCM10000071d6of8gRCRD (accessed Feb. 13. 2017)

23. Sally Han, interview by author.

24. City of Toronto, "Report for Action."

25. Sally Han, interview by author.

26. City of Toronto, "Report for Action."

27. Ibid., 4
South and Central America has had a deep impact on Canada's population, increasing the percentage of non-white ethnic groups. ${ }^{17}$

Fourth, the wish of ethno-cultural groups to produce official public monuments has been influenced by the contemporary culture of public commemoration, particularly visible in Western societies. ${ }^{18}$ In the memorialization process, victims of slavery, terrorism, genocide, and totalitarian regimes come to the fore, often alongside petitions for reparation. All this has triggered an imperative to critically explore new strategies and forms of memorialization: what and who is worthy of commemoration, and how does a society or city effectively remember (and forget)?

\section{Public Art in Toronto: Managing Demands for Commemoration}

How does the City of Toronto manage proposals for commemorative public art today? According to Bogart, the ACNY was created in response to a new interrogation of the role of public monuments in New York on the threshold of the twentieth century: "Which groups had a legitimate claim to commemoration on public property in a diverse and democratic modern city? Who was worthy of being commemorated?" 19 More than a century later, Toronto's municipal administration appears to face similar questions.

Commemorative works erected on public grounds in Toronto fall under the administration of Arts and Culture Services, which administers the City's public art and monument collection. In fact, works with a commemorative purpose make up a third of this collection. The City has no separate funds for erecting memorials and monuments: ${ }^{20}$ they are either initiated by non-governmental actors and secured by private funds, ${ }^{21}$ or they are the result of provincial and federal initiatives, as was the case with the Air India Memorial (Humber Bay Park, 2007).

In 2001, the City approved an Official Gifts and Donations Policy. ${ }^{22}$ No ethno-cultural monument has been integrated into the City collection since then, except for the Memorial to John Lombardi (2004) and the Holodomor Memorial (2018), which commemorates the Ukrainian famine of the early 1930s. However, ethno-cultural groups have continued to apply pressure on the municipal government and to make demands for commemoration. There were five such requests in 2016, none of them politically neutral. Given this fact, the City of Toronto resolved to develop a new public art donation policy. ${ }^{23}$

The policy approved by the City Council on January 31, 2017, provides "prospective donors with a well-defined administrative process, a clear set of technical, aesthetic, thematic and location selection criteria, and a public consultation process that will be evaluated by City staff for each individual donation proposal." ${ }^{24}$ The new document seeks to ensure that subjects of commemoration have relevance to the larger population as well as to the donors. ${ }^{25}$ The donation guidelines were revised not only because of the increased number of commemoration demands, but also because some themes and subjects are politically or culturally sensitive. ${ }^{26}$ The municipal policy document states that:

For commemorative donations, the theme of the proposed work must feature a significant contribution from Canadians, or be an event that occurred in Canada. If the event the donor wishes to commemorate neither occurred in Canada nor prominently features Canadians, then the event being commemorated must be officially recognized by the Government of Canada. ${ }^{27}$ 
28. City of Toronto, "Official Gift Donations."

29. On this concept, see: Arjun Appadurai, Modernity at Large: Cultural Dimensions of Globalization (Minneapolis and London: Univerity of Minnesota Press, 1996).

30. Ibid., 182.

31. Malcolm Miles, Art, Space and the City (Florence, us: Routledge, 1997).

32. Sergiusz Michalski, Public Monuments: Art in Political Bondage 1870-1997 (London: Reaktion Books, 1998), 8-9.

33. Annie Gérin, "Introduction: Off Base," in Public Art in Canada: Critical perspectives, ed. Annie Gérin and James S. McLean (Toronto: University of Toronto Press, 2009), 12.
This policy contrasts strikingly with the rescinded 2001 donation guidelines, which simply stated that "the City requires a written submission with a detailed description of the gift, [and] the relevance of the subject matter to the City of Toronto." ${ }^{28}$ The new guidelines reflect the municipal administration's obvious mandate to achieve social cohesion. But does the new policy still support multiculturalist inclusiveness? How will the City of Toronto's staff execute this policy without risking the exclusion of some groups and issues? It is certainly difficult to determine what is relevant to Canada and what is not, since who we are is deeply entwined with who we were and where we come from, and with the histories of our ancestors. I will return to this question later.

\section{Ethno-Cultural Monuments in Toronto: Major Issues and Controversies}

Though they are often barely noticeable in urban landscapes, ethno-cultural monuments do contribute to the "production of locality." ${ }^{29}$ Social-cultural anthropologist Arjun Appadurai identifies "locality" as a "phenomenological property of social life, a structure of feeling that is produced by particular forms of intentional activity and that yields particular sorts of material effects. ${ }^{30}$ Ethno-cultural monuments are forms of intentional place and identity building that can be understood simultaneously as assertions of power over particular areas as well as social agents fostering a sense of belonging or neighborhood.

On the other hand, in publicly channelling a vision of the world or a historical interpretation, many ethno-cultural monuments also seek to legitimize what is represented. There is nothing new about monuments' capacity to normalize official claims. For example, they can convey or reiterate democratic values, colonial versions of the past, or totalitarian ideologies. Since the second half of the nineteenth century, nation-states in the making have promoted themselves through public monuments as a way to ritualize and symbolize dominant or aspirant narratives. In that sense, monuments can be understood as a device of social control and hegemony for implementing a national history. ${ }^{31}$ Sergiusz Michalski explains that "At some time in the 1870 , the erecting of public monuments became an artistic, political and social domain in its own right." ${ }^{32}$ However, this article looks into Canadian monument production that has generally been the result of grassroots initiatives, initiatives driven by population groups rather than by governmental actors.

In a continually shifting Canadian context, as immigrants continue to come from throughout the world, this form of commemoration "from below" can lead to intense public disagreements. Controversy can be exacerbated by the fact that not all ethno-cultural monuments are or are meant to be situated in "ethnic neighborhoods." On the contrary, as some case studies below demonstrate, they seek instead to insert the statements they bear into the larger public sphere-a sphere understood here as an arena of public discourse-by occupying visible and central sites in Toronto's urban fabric.

As Canadian art historian Annie Gérin explains, "commemorative activity is highly political and involves a power struggle over who and what is to be remembered or forgotten." ${ }^{33}$ Ethno-cultural monuments typically encompass multiple and difficult negotiations over their siting, the commemorated 
34. In light of the \#MeToo movement's 2018 rise, eighteenth-century Scottish poet Robert Burns's behavior came under scrutiny over his treatment of women. See John Dugdale, "Robert Burns: was the beloved poet a 'Weinsteinian sex pest'?," The Guardian, Jan. 24, 2019, https:// www.theguardian.com/books/ booksblog/2018/jan/24/robertburns-was-the-beloved-poet-aweinsteinian-sex-pest (accessed Jan. 5, 2019).

35. Noula Mina, Homeland Activism, Public Performance, and the Construction of Identity: An Examination of Greek Canadian Transnationalism, 1900s-1990s, Ph.D. diss. (Department of History, University of Toronto, 2015).

36. Ibid., 192

37. Kim Honey, "They both came to claim Alexander the Great as their king," Toronto Star, Jul. 30, 1990: A7.

38. Michael Tenszen, "Police arrest 4 in argument over statue of Alexander," Toronto Star, Jul. 22, 1991: A7.

39. "Alexander's bust should be removed," (reader's letter), Toronto Star, Aug. 4, 1991: B2.

40. City of Toronto, Executive Committee consideration, "Commemorating the 10oth Anniversary of the Armenian Genocide," Apr. 23, 2014, http://app.toronto.ca/ tmmis/viewAgendaltemHistory. do? item=2014. EX41.24 (accessed 13 Feb. 2017).

41. The Federation of Canadian Turkish Associations, "Say NO to Motion MM50.5 at City Hall," press release, Toronto, Apr. 23, 2014, http://www.toronto.ca/legdocs/ mmis/2014/ex/comm/communicationfile-46927.pdf (accessed 13 Feb. 2017). subject's "appropriateness," and their aesthetic value. In what follows, I look into lines of controversy associated with these artifacts, mainly in relation to the re-rooting of extra-national narratives in Canadian soil.

\section{Competing, Contested, or Sensitive Narratives in the Public Realm}

In contrast to the Burns and Sibelius examples noted above, which celebrate traditionally unchallenged national figures, ${ }^{34}$ a significant number of ethno-cultural monuments in Toronto represent contested or controversial histories, reifying one or another version of the past. Therefore, their erection can lead to ideological and even physical clashes among ethno-cultural communities in the public realm.

Greektown, a neighborhood in east Toronto, became an arena of debate over the identity of Alexander the Great when several Greek organizations jointly funded a bronze bust of Alexander, which was unveiled in May 1990 at a park on the corner of Danforth and Logan Avenues. ${ }^{35}$ Alexander the Great was and is at the center of a historical argument between Greece and Macedonia, since both nations claim him as their king, and almost immediately after the artwork's dedication, citizens of Macedonian descent objected "to the wording of the plaque that identified Alexander as 'King of the Greeks' rather than 'Alexander, King of the Macedonians.'" ${ }^{36}$ Two months later, on the anniversary of Alexander's birth, the city's Greeks and Macedonians clashed in front of the bust. ${ }^{37}$ The following summer, another violent incident broke out when members of the United Macedonian Diaspora attempted to mark Alexander's birth with a wreath-laying. They were stopped by the hundreds of Greek protesters who gathered at the site. ${ }^{38}$ Some Torontonians suggested the removal of the bust after these incidents. ${ }^{39}$ However, the bronze of Alexander still stands.

The easy access to the bust of Alexander, as well as its governmental sanction-implicit in the fact that it was erected on City-owned land-certainly contributed to its polemical reception. Indeed, in spite of potential controversies, some communities consider it essential to tell their stories in highly visible places and to obtain governmental approval and support for their projects. This might explain why, in 2014, Toronto's Armenian Community, via the Armenian National Committee, proposed to the City of Toronto to either donate an existing artwork or go through the process of having one commissioned to commemorate the 1.5 million victims of the Ottoman Armenian genocide between 1915 and $1917 .{ }^{40}$ Although two monuments to the genocide victims already stand in Toronto, they are situated on the grounds of Armenian churches. The new memorial proposal would have been acceptable even under the more restrictive requirements of the 2017 public donation policy since the federal government officially recognized the Armenian Genocide in 2004. However, this crime is still an intensely political topic, and it continues to bring Armenians and Turks into conflict all over the world. The proposal failed. There is evidence that the City of Toronto received strong opposition from the Turkish community, mainly through the Federation of Canadian Turkish Associations. ${ }^{41}$ Other reasons, whether technical, financial, or artistic, might have delayed or thwarted the proposal, but its intrinsically controversial nature appears to have been the main reason for its unsuccessful outcome: it would potentially erode social cohesion. 
These two examples of proposals and existing ethno-cultural monuments illustrate the potential conflict they can engender between different ethno-cultural groups in Toronto. Yet such cultural artifacts can also tear apart a single

42. City of Toronto Archives, Fonds 1306, Serie 310, Subseries 1, File 20, "Grange Park, Dr. Sun Yat Sen Statue," Box 145, Folio 3. Letter from C. Grant, chairman of the Selection committee for Public Art to the Chinese Canadian Committee for Sun Yat Sen Statue (draft), 1983: 1.

43. City of Toronto Archives, Fonds 1306, Serie 310, Subseries 1, File 20, "Grange Park, Dr. Sun YatSen Statue," Box 145, Folio 3. Lette from Peggy Gale, chairman of the Selection committee for Public Art to the City's executive committee, Feb. 26, 1982:3

44. City of Toronto Archives, Fonds 1306, Serie 310, Subseries 1, File 20, "Grange Park, Dr. Sun YatSen Statue," Box 145, Folio 3. Re: Sun Yat-Sen Statue Committee. Letter from Moon Lum, chairman of the Chinese Canadian Committee for Dr. Sun Yat-Sen Statue, to Jack Layton Alderman, New City Hall, Toronto, Aug. 5, 1983.

45. At the time, many Chinese Canadians expressed their opinion and viewpoints pertaining to this issue in Toronto's local press. See: City of Toronto Archives, Fonds 1306, Serie 310, Subseries 1, File 20 "Grange Park, Dr Sun Yat Sen Statue," Box 145, Folio 3. "Sun Yat-sen a hero, but not a Canadian," The Global and Mail, March 28, 1981; "Statue would mark 'power of education'," "Statue of Sun Yat-sen 'wrong choice'," "Controversy 're-opens some old wounds," Toronto Star, March 20, 1981.

46. City of Toronto Archives, Fonds 1306, Serie 310, Subseries 1, File 20, "Grange Park, Dr. Sun YatSen Statue," Box 145, Folio 3. Re: Dr. Sun Yat-Sen Statue. Letter from Doug Hum to John Sewell, Jul. 21, 1983.

47. Benedict Anderson, Imagined Communities: Reflections on the Origin and Spread of Nationalism (London: Verso, 1983).

48. Shaun Merritt, "Memorial to Commemorate the Chinese Railroad Workers in Canada," Spacing Toronto, Apr. 9, 2009, http://spacing.ca/toronto/2009/04/09/memorial-to-commemorate-the-chinese-railroad-workers-in-canada/ (accessed Feb. 5, 2017).

49. James Young, "Memory and the End of the Monument," in Image and Remembrance: Representation and the Holocaust, eds. Shelley Hornstein and Florence Jacobowitz (Indiana University Press, 2003), 63. ethnic group. That was the case with two monuments that polarized the Toronto Chinese community in the 1980 s.

Orchestrated by the Canadian Chinese Committee, a public art competition was held in Toronto in 1983 for a statue of Sun Yat-Sen, Chinese philosopher and revolutionary. Toronto artist Joe Rosenthal won the national contest, but the City's selection committee for public art rejected his work, arguing that "the sculpture was found wanting in power, freshness and imagination." ${ }^{42}$ The committee had originally encouraged "the proponents of the statue to enlarge the parameters of their proposal to create a memorial which would be meaningful to a broad spectrum of Torontonians - present and future." ${ }^{43}$ If quality, thematic, and location concerns were deeply problematic-the Canadian Chinese Committee wanted a visible City-owned park and priority location such as Harbourfront, Allan Gardens, High Park, or Grange Park $-{ }^{44}$ one of the main points of contention was whether or not to commemorate, on Canadian soil, a figure whose impact and actions concerned a foreign country. ${ }^{45}$ The argument was brought up by those advocating for a Chinese Railroad Workers Memorial. | fig. 3 | They claimed that it would be more appropriate to commemorate the "silent pioneers who built the transcontinental railway [Canadian Pacific Railway] and thus built a nation." ${ }^{46} \mathrm{Here}$ is a clear example that a focus on "Canadianness" might also constitute a central concern for ethno-cultural communities which are frequently understood as cohesive "imagined communities," ${ }^{47}$ but which are actually marked by political, religious, and even cultural differences.

Both monuments were finally erected within a five-year time frame. Despite opposition, the City council accepted the Sun Yat-Sen statue, which has stood since 1984 in Riverdale Park, near East Chinatown. The Chinese Railroad Workers Memorial, made primarily of wood and metals, was unveiled in 1989 at the intersection of Blue Jays Way and Navy Wharf Court, an equally prominent site. New wreaths can be frequently found at the foot of that memorial. ${ }^{48}$ But a question remains: should monuments and memorials erected on Canadian soil exclusively commemorate events related to Canada? In fact, Toronto's new donation policy seems to privilege local narratives. Nevertheless, for some ethno-cultural groups, narratives attached to their homeland are pillars of their collective identity and help to unify their members in diaspora.

\section{Commemorating Victims of Totalitarian Regimes}

Discussing the struggle of German contemporary artists with monumental forms in light of their country's fascist past, scholar James Young remarks: "How else would totalitarian regimes commemorate themselves except through totalitarian art like the monument?"49 However, the traditionally didactic logic of monuments has turned against those regimes, for today they can also serve as a tool in the hands of those who suffered totalitarian repression. Immigrant groups in Canada have used monuments to denounce 


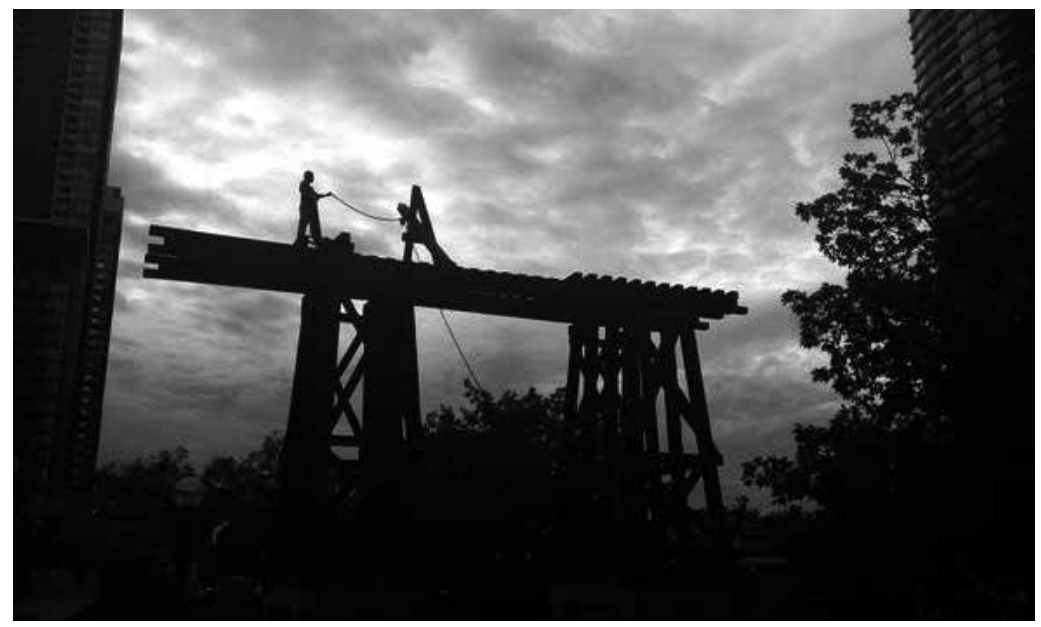

Figure 3. Eldon Garnet and

Francis LeBouthillier. Chinese

Railroad Workers Memorial.

Blue Jays Way and Navy Wharf

Court, Toronto. 1989. Wood and

bronze. Photo by the author.

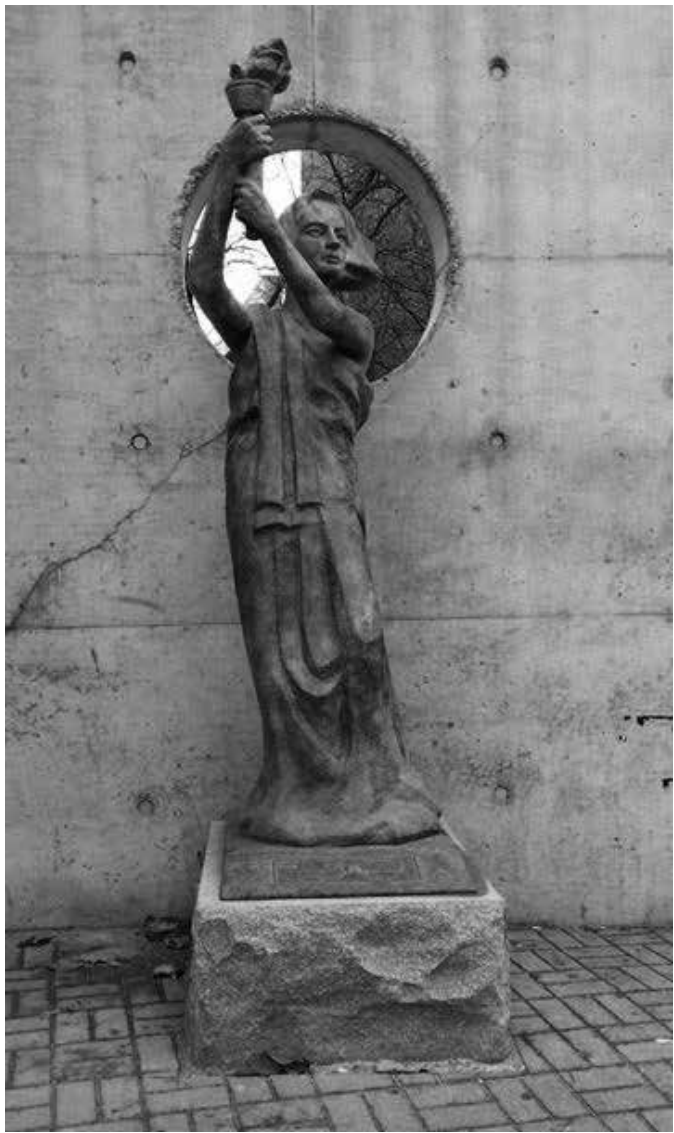

Figure 4. Ruth Abernethy. Goddess of Democracy. York University Student Centre,

Toronto. 2012. Bronze. Photo by the author. 
50. "Russian Parliament Condemns Stalin for Katyn Massacre," BBCNews, Nov. 26, 2016. http:// www.bbc.com/news/world-europe-11845315

51. I believe Ottawa's representative was Jesse Philip Flis, former member of the Parliament for Parkdale-High Park, a federal electoral district in Ontario. Flis, however, attended the memorial dedication in a private capacity. See, Andrew Tarnowski, "Ottawa Snubs Unveiling of Monuments to Poles," Toronto Star, Sep. 15, 1980: A3.

52. Ibid.

53. See, Rosie DiManno, "Poles Mark Wartime Massacre 2,000 Pay Tribute to Katyn Victims at Stark Memorial in Parkdale Area," Toronto Star, Apr. 23, 1990: A7.

54. See, Don Butler, "A monumental controversy: History of the Memorial to Victims of Communism," The Ottawa Citizen, Mar. 7, 2015: B1.

55. On how the Chinese government has undermined the extend of these student demonstrations, see: Peter Li, Marjorie H. Li, and Steven Mark, eds., Culture and Politics in China: An Anatomy of Tiananmen Square (New Jersey: Transaction Publishers, 2011)

56. Jan Wong, "Tiananmen Square is so last-century," The Globe and Mail, May 29, 2004: M3; The Globe and Mail, "Tiananmen plaque stolen," Saturday, Jun. 6, 1992: A13.

57. See, "York statue draws anger of Chinese," Toronto Star, Jun. 3, 1992: A3; "York students endorse statue despite protest by Chinese," Toronto Star, Jun. 4, 1992: A3. the crimes of totalitarian regimes in their original home countries. But conflict may arise when immigrant populations build commemorative works that denounce totalitarian regimes which are still in power, or memorialize crimes or tragedies that have not been officially recognized by their new homeland's governments. This is evidenced through the commemorative projects stemming from local Polish and Chinese communities discussed below, all of them linked to past and current Communist regimes.

Located within the heart of the local Polish community, at the foot of Roncesvalles Avenue, on City land, the Katyn Memorial stands for the 15,000 Polish people who went missing at the hands of the Soviet secret police in 1940. The Russian government has refused to classify the Katyn Forest massacre as a war crime or an act of genocide, although the Russian lower house of parliament, The Duma, did so in 2010. ${ }^{50}$ The dedication of the Katyn Memorial in Toronto was marred by the potential for scandal: on the day the memorial was inaugurated, September 14, 1980, the Canadian federal government officially withdrew "its representative at the last minute without explanation." ${ }^{51}$ Ottawa and Edmonton had previously rejected the memorial proposal, arguing it would harm Canada's relation with Poland and the Soviet Union. ${ }^{52}$ Curiously, the Canadian government, which publicly refused to get involved in the construction of the Katyn Memorial, ${ }^{53}$ decided thirty years later to commission, in the national capital, a monument to all victims of totalitarian Communism. ${ }^{54}$

Toronto hosts other ethno-cultural monuments commemorating victims of Communist regimes, including two that pay tribute to the Tiananmen uprising, when, on June 4, 1989, Chinese military forces violently suppressed student-led demonstrations in Beijing's Tiananmen Square. This standoff remains one of the most sensitive political topics in China and it has thus been partially erased from the country's public discourse. ${ }^{55}$ Unveiled in 1992, the bronze wall sculpture Broken Bicycle is installed behind the University of Toronto Students' Union building. It commemorates the Tiananmen massacre through an austere but poignant symbolic statement. Created by Bruce Parsons and Gu Xiu Hei, both members of a group of students, artists, and designers going by the name of Design for Democracy, the sculpture depicts a bicycle crushed by tank treads and a pair of slippers. It appears that this work of commemoration was, in fact, a replacement project. The Toronto Association for Democracy in China had offered the University of Toronto a replica of the Goddess of Democracy, a temporary plaster of Paris statue drawing upon New York's Statue of Liberty that was erected in Tiananmen Square during the 1989 protests. Because of possible repercussions and censorship from China, the University of Toronto administration declined the gift. The crushed-bicycle sculpture replaced the statue and was put up on a site beyond the university administration's control. Despite the seeming neutrality of the site of Broken Bicycle, the plaque identifying the sculpture has been repeatedly vandalized over the years. ${ }^{56}$ The rejected Goddess of Democracy was placed in 1992 at the York University Student Centre, where the university administration similarly had no jurisdiction. Again, in spite of its location in a site without official sanction, the consulate of China in Toronto addressed a letter to York University President Harry Arthurs expressing discontent over it. ${ }^{57}$ The University did not surrender to the pressures, and the statue remained on display until 2011, 
when new pressures from the Chinese consulate finally led to the statue's removal. ${ }^{58}$ However, the Toronto Association for Democracy in China managed to raise funds to build a bronze version by artist Ruth Abernethy, which has stood outside the Student Union building since 2012. | fig. 4 |

\section{Conclusion: Alternative Avenues of Remembrance}

The analysis conducted above helps us understand the reticence of the City of Toronto to fund or allow the construction, on public land, of permanent artworks commemorating conflictual situations or politically sensitive events. Yet, in a country that recognizes the contribution of each culture to the nation, and where transnational movements and connections are strengthening every day, is this reticence appropriate? Toronto's new public art donation policy might appear incompatible with Canadian multiculturalism laws. The Canadian Multiculturalism Act (1988) points out "the right of Canada's ethnic, racial and religious minorities to preserve and share their unique cultural heritage." ${ }^{59} \mathrm{In}$ the same way that food, dance, music, or cinema festivals do, monuments and memorials share and communicate a cultural heritage. Of course, these other

58. Bob San, "Tiananmen Massacre Remembrance in Toronto," Asian American Press, Jun. 10, 2012. http://aapress.com/ethnicity/chinese/tiananmen-massacre-remembrance-in-toronto/ (accessed 717 Jan. 2017).

59. Ilene Hyman, Agnes Meinhard, and John Shields, "The Role of Multiculturalism Policy in Addressing Social Inclusion Processes in Canada," Working paper series 3 (Ryerson University, 2011). http://www. ryerson.ca/content/dam/cvss/ reports $/ 2011 \% 20 v 3 \% 20$ The $\% 20$ Role.pdf

60. Patricia C. Phillips, "Temporality and Public Art," in Critical Issues in Public Art: Content, Context, and Controversy, eds. Harriet F. Senie and Sally Webster (New York: Icons Editions, 1992), 303.

61. Ibid., 304

62. Claire Doherty, ed., Out of Time, Out of Place: Public Art (Now) (London: Art Book Publishing Ltd., 2015).

63. I am thinking in particular of the artwork One and Other, by artist Antony Gormley, commissioned in 2009 for the Fourth Plinth in London's Trafalgar Square. The collective performance involved more than 2000 people, who each occupied the pedestal for one hour over one hundred days.

64. On virtual memorials, see Annie Gérin, "The Virtual Memorial: Temporality, Interactivity, and the Internet," Canadian Art Review 31.1-2, 2006: 42-56; Analays Alvarez Hernandez, "Mémoriaux Facebook: la commémoration à l'enseigne du virtuel," Archée 5, Dec. 2016, http://archee.qc.ca/images/ edito-2016-12/Archee_2016_12_ MemoriauxFacebook.php ethno-cultural expressions, even if they are seen in Toronto throughout the year, are generally temporary events, and are thus more easily accepted. And, as evidenced throughout this paper, ethno-cultural monuments in Toronto are almost always permanent sculptural or architectural works.

However, Patricia C. Phillips argues that "public art does not have to last forever." ${ }^{60}$ She concludes her seminal essay "Temporality and Public Art" by explaining that: "The temporary provides the flexible, adjustable, and critical vehicle to explore the relationship of lasting values and current events, to enact the idea of the commons in our own lives." ${ }^{61}$ Reflection upon the life or display cycle of works in public spaces, whether short-lasting interventions or long-term projects, might generate new considerations of temporal specificity alongside imperative considerations of site-specificity. ${ }^{62}$ Fixing boundaries upon the narratives that may be channeled through public art, as Toronto's new public art policy does, might be necessary, but it does not constitute a permanent solution. Solutions may lie instead in opting for short-lived art projects or in raising awareness about contemporary artistic practices as a way to increase opportunities for social cohesion.

An appealing model is provided by national and international permanent public art programs that offer temporary "shelter" (through a permanent display system) for artworks. Prominent examples include the Mayor of London's Fourth Plinth Commission, in Trafalgar Square, the forthcoming High Line Plinth program in New York, and the Vancouver Art Gallery's public art program Offsite, an outdoor exhibition space featuring cutting-edge temporary public art projects by local and international contemporary artists. Similar permanent platforms could temporarily host contemporary artworks, whether sculpture, media-based, or participatory projects, ${ }^{63}$ that represent ethno-cultural histories and eventually serve as fora for public debate. Nonetheless, podiums that host public art for a limited period of time are the outcome of programs that require substantial funds and a high level of coordination and logistics. Ethno-cultural groups, no matter how well organized they are, could not afford these initiatives without government support. 
65. According to Sally Han (interview by author), the Holodomor Memorial proposal was approved in large part because the donator, the Toronto Branch of the Ukrainian Canadian Congress, provided a substantial upfront sum for the artwork's commission and maintenance.

66. Bogart, The Politics of Urban Beauty, 273 .

67. In 2017, a (new) statue of Sun Yat-Sen was erected in downtown Toronto's Chinatown, at Spadina Avenue and Dundas Street West. Like most recent ethno-cultural monuments in Toronto, it stems solely from community efforts and is placed on private land. Xinsheng (Simon) Zhong, Executive Director, Toronto Community \& Culture Centre, personal communication, Jan. 25, 2017.
Furthermore, powerful temporary or temporarily displayed art projects might oppose or compromise the original notion of the monument, which has historically been created to recall for future generations the things, values, people, or events that matter for the generation who erected it, and which has provided a place for commemorative activity. Perhaps communities and municipal authorities should further explore virtual space, where artists and groups of victims are already "erecting" memorials. ${ }^{64}$

In conclusion, despite the restrictive character of Toronto's new public art donation policy, the door remains open to individuals and groups which are able to respect the donation guidelines' artistic, thematic, and financial criteria, and which count on their economic and political influence at different levels of government. ${ }^{65}$ This case-by-case strategy allows public officials to approve those proposals that reflect their own social and political views, aesthetic leanings, and urban planning projections. As Bogart remarks, "Cooperation and compromise on the part of the commissioners [ACNY's members] occasionally proved to be more productive than rigid adherence to ideal of judgment." 66 However, as long as Toronto's municipality does not find a better and more "permanent" solution for managing commemorative proposals, and as long as the privatization of public and civic spaces continues, ${ }^{67}$ existing and future ethno-cultural monuments will potentially disrupt Toronto's commemorative landscape. 